There is some anecdotal evidence that oxygen-ozone therapy may be beneficial in some human diseases. However so far only a few biochemical and pharmacodynamic mechanisms have been elucidated. On the basis of preliminary data we postulated that controlled ozone administration would promote an oxidative preconditioning preventing the hepatocellular damage mediated by free radicals. Six groups of rats were classified as follows: (1) negative control, using in traperitoneal sunflower oil; (2) positive control using carbon tetrachloride $\left(\mathrm{CCl}_{4}\right)$ as an oxidative challenge; (3) oxygen-ozone, pretreatment via rectal insufflation ( 15 sessions) and after it, $\mathrm{CCl}_{4}$; (4) oxygen, as group 3 but using oxygen only; (5) control oxygen-ozone, as group 3, but without $\mathrm{CCl}_{4}$; group (6) control oxygen, as group 5, but using oxygen only. We have evaluated critical biochemical parameters such as levels of transaminase, cholinesterase, superoxide dismutase, catalase, phospholipase A, calcium dependent ATPase, reduced glutathione, glucose 6 phosphate dehydrogenase and lipid peroxidation. Interestingly, in spite of $\mathrm{CCl}_{4}$ administration, group 3 did not differ from group 1, while groups 2 and 4 showed significant differences from groups 1 and 3 and displayed hepatic damage. To our knowledge these are the first experimental results showing that repeated administration of ozone in atoxic doses is able to induce an adaptation to oxidative stress thus enabling the animals to maintain hepatocellular in tegrity after $\mathrm{CCl}_{4}$ poisoning.

Key words: Ozone, Oxidative stress, Preconditioning, Free radicals, Antioxidant defence system

\section{Ozone oxidative preconditioning: a protection against cellular damage by free radicals}

\author{
O. S. León, ${ }^{1, \mathrm{CA}}$ S. Menéndez, ${ }^{2}$ N. Merino, ${ }^{3}$ \\ R. Castillo, ${ }^{1}$ S. Sam, ${ }^{1}$ L. Pérez, ${ }^{1}$ E. Cruz ${ }^{1}$ and \\ V. Bocci $^{4}$
}

${ }^{1}$ Center for Research and Biological Evaluation (Pharmacy Institute of Havana University), Havana; ${ }^{2}$ Ozone Research Center, Havana, Cuba; ${ }^{3}$ National Center for Scientific Research, Havana, Cuba;

${ }^{4}$ Institute of General Physiology, University of Siena, Siena, Italy
${ }^{\mathrm{CA}}$ Corresponding Author
Tel: $(+53) 7219264$ or 7219537
Fax: (+53) 7210233
Email: ozono@infomed.sld.cu

\section{Introduction}

Ozone $\left(\mathrm{O}_{3}\right)$ has been used as a therapeutical agent for the treatment of different, apparently nonrelated diseases and beneficial effects have been observed in cerebrovascular ischaemia, ${ }^{1}$ chronic ulcers, ${ }^{2}$ arteriosclerosis obliterans, ${ }^{3}$ retinitis pigmentosa, ${ }^{4}$ humoral immunity deficiency, ${ }^{5}$ hepatic steatosis, ${ }^{6}$ and heart ischaemia. $^{7}$ In spite of these encouraging results obtained with ozonetherapy, its clinical use remains controversial due to the scarce knowledge of the biochemical and pharmacodynamic mechanisms which underlie its therapeutic action and the efficacy in such heterogeneous pathologies. Last but not least, $\mathrm{O}_{3}$ has been associated with environmental pollutions and to different pathologies. ${ }^{8-10}$ These factors have contributed to scepticism and prejudice of official medical authorities, delaying the acceptance of ozonetherapy. In order to provide scientific support to the aforementioned clinical data, some experimental strategies have been developed in order to increase our knowledge concerning its probable mechanisms of action. On the basis of the oxidant properties of $\mathrm{O}_{3}$ and on the possibility that specific cell sensors activated by lipid oxidation products (LOP) may upregulate the antioxidant system, we postulate that $\mathrm{O}_{3}$ may induce an adaptation to oxidative stress. Moreover, not only $\mathrm{O}_{3}$ could induce tolerance to itself but it could prepare the host to face physiopathological conditions mediated by reactive oxygen species (ROS). With the aim to demonstrate the capability of $\mathrm{O}_{3}$ to promote an oxidative preconditioning process, we induced hepatocellular damage with a single dose of carbon tetrachloride $\left(\mathrm{CCl}_{4}\right)$, which is a recognized organic agent able to produce a cellular injury through generation of free radicals. ${ }^{11}$

\section{Materials and Methods}

\section{Animals and sample preparation}

Adult female Sprague-Dawley rats $(220-250$ g) were used for these studies. Rats were maintained in an air filtered and temperature conditioned $\left(20-22^{\circ} \mathrm{C}\right)$ room with a relative humidity of $50-52 \%$ Rats were fed with standard commercial pellets and water ad 
libitum. $\mathrm{O}_{3}$ was gene rated by an OZOMED equipment manufactured by the Ozone Research Center (Cuba) and was administered by rectal insufflation. $\mathrm{O}_{3}$ obtained from medical grade oxygen was used immediately and it represented only about $3 \%$ of the gas $\left(\mathrm{O}_{2}+\mathrm{O}_{3}\right)$ mixture. The $\mathrm{O}_{3}$ concentration is measured by using an UV spectrophotometer at $254 \mathrm{~nm}$ and is very precise. The ozone dose is the product of the $\mathrm{O}_{3}$ concentration (expressed as $\mathrm{mg} / \mathrm{l}$ ) by the gas $\left(\mathrm{O}_{2}+\mathrm{O}_{3}\right)$ volume (l). By knowing the body weight of the rat the $\mathrm{O}_{3}$ dose is calculated as $1 \mathrm{mg} / \mathrm{kg}$. Rats received 15 ozone treatments, one per day, $4.4-5.0 \mathrm{ml}$ with $\mathrm{O}_{3}$ concentration of $50 \mu \mathrm{g} / \mathrm{ml}$ be fore challenge with $\mathrm{CCl}_{4}$. After the last ozone treatment, rats received $\mathrm{CCl}_{4}(1 \mathrm{ml} / \mathrm{kg})$ by intraperitoneal administration of a solution of $10 \% \mathrm{CCl}_{4}$ in sunflower oil. The animals were euthanized by ether anaesthesia, $24 \mathrm{~h}$ after receiving $\mathrm{CCl}_{4}$. Immediately after, blood samples were obtained from the abdominal aorta and mixed with $3.8 \%$ sodium citrate, used as an anticoagulant, for biochemical determinations. Afterwards, some representative samples of different liver portions were taken for histopathological studies and tissue homogenates. Liver homogenates were obtained using a tissue homogenator Edmund Bulher LBMA at $4^{\circ} \mathrm{C}$. The homogenates were prepared by using a $50 \mathrm{mM} \mathrm{KCl} /$ histidine buffer $\mathrm{pH} 7.4,1: 10(\mathrm{w} / \mathrm{v})$ and were spun down with a Sigma Centrifuge $2 \mathrm{~K} 15$, at $4^{\circ} \mathrm{C}$ and $8500 \times \boldsymbol{g}$ for $20 \mathrm{~min}$. The supernatants were taken for biochemical determinations.

\section{Treatment schedule}

The protocol consisted of six experimental groups $(n=60)$. (1) negative control group treated only with sunflower oil by intraperitoneal route; (2) positive control group using $1 \mathrm{ml} / \mathrm{kg}$ of $10 \% \mathrm{CCl}_{4}$ solution; (3) ozone $\left(\mathrm{O}_{3}\right)$ group receiving $15 \mathrm{O}_{3}$ treatments $(1 \mathrm{mg} /$ $\mathrm{kg})+\mathrm{CCl}_{4}(1 \mathrm{ml} / \mathrm{kg}) ;(4)$ oxygen $\left(\mathrm{O}_{2}\right)$ group with 15 $\mathrm{O}_{2}$ treatments $(26 \mathrm{mg} / \mathrm{kg})+\mathrm{CCl}_{4}(1 \mathrm{ml} / \mathrm{kg}) ;(5) \mathrm{O}_{3}$ control group with $15 \mathrm{O}_{3}$ treatments $(1 \mathrm{mg} / \mathrm{kg})$; (6) $\mathrm{O}_{2}$ control group with $15 \mathrm{O}_{2}$ treatments $(26 \mathrm{mg} / \mathrm{kg})$.

\section{Biochemical determinations}

The biochemical parameters were determined by spectrophotometric methods using an Ultraspect Plus Spectrophotometer from Pharmacia LKB. Aspartic alanine transaminase (ASAT) and cholinesterase (CHEase) levels were measured in plasma using standard commercial kits produced by Boehringer Mannheim. In liver, homogenates were assayed for total superoxide dismutases ( $\mathrm{Cu} / \mathrm{Zn}$ and $\mathrm{Mn}$ SODs) activity determining the capacity of the enzyme in inhibiting the autoxidation of pyrogallol by $50 \%{ }^{12}$ The catalase concentration was measured through the catalytic activity which promotes the reduction of hydrogen peroxide $\left(\mathrm{H}_{2} \mathrm{O}_{2}\right)$ to oxygen and water. ${ }^{13}$
The phospholipase A activity was determined according to a standard procedure. ${ }^{14}$ Lipid peroxidation was assessed by reading thiobarbituric acid-reactive substances (TBARM). ${ }^{15}$ The determination of the activity of calcium-dependent ATPase (Ca-ATPase) ${ }^{16,17}$ and glucose-6-phosphate dehydrogenase (G6PD) ${ }^{18}$ were carried out as described. After precipitation of thiol proteins using 10\% TCA the reduced gluthatione levels (GSH) were determined in supernatants of $10 \%$ $\mathrm{w} / \mathrm{v}$ homogenates. ${ }^{19}$ The proteins were measured by a standard Coomassie Blue method. ${ }^{20}$

\section{Histological study}

Samples of rat liver were taken and fixed in neutral $10 \%$ formalin, processed and embedded in paraffin. The histological sections were stained with haematoxylin and eosin. In addition, neutral lipids were demonstrated with oil red staining in frozen sections. From the sections embedded in paraffin and after a previous study of the microscopic alterations, the cells with ballonic degeneration were counted at the zone III of the Rappaport acini. Ten fields were taken, at random, per animal with a magnification of $250 \times$ and the count made in a blind way by two pathologists. From the frozen sections stained with oil red, the damage area by lipidosis was calculated in other 10 fields per animal, using a morphometric software system. $^{21}$

\section{Statistical analysis}

The statistical analysis was started by using the OUTLIERS preliminary tests for detection of error values. Afterward, the Anova method (Single Way) was used followed by homogeneity variance test (BartlettBox). In addition, a multiple comparison test was used (Duncan test); values are expressed by the mean \pm standard error of mean ( $n=10$ per group). Different letters indicate a statistical significance of at least $P<$ 0.05 .

\section{Results}

Figure 1 shows the mean values \pm SEM of the biochemical parameters measured for the first four groups of treatments. Groups treated w ith either $\mathrm{CCl}_{4}$ or $\mathrm{O}_{2}+\mathrm{CCl}_{4}$, showed a significant increase of ASAT activity in comparison with both the control and $\mathrm{O}_{3}+$ $\mathrm{CCl}_{4}$ groups. In contrast $\mathrm{CHEase}$ activity for the $\mathrm{CCl}_{4}$ and $\mathrm{O}_{2}+\mathrm{CCl}_{4}$ treatment groups was reduced significantly in comparison with both the $\mathrm{O}_{3}+\mathrm{CCl}_{4}$ and control groups. A similar trend has been observed for SODs activity although the $\mathrm{O}_{2}+\mathrm{CCl}_{4}$ group has an enzymatic activity significantly lower than the $\mathrm{CCl}_{4}$ group. Catalase levels increased in $\mathrm{CCl}_{4}$ and $\mathrm{O}_{2}+\mathrm{CCl}_{4}$ treatment groups, while no modifications were observed under $\mathrm{O}_{3}+\mathrm{CCl}_{4}$ treatment group with 

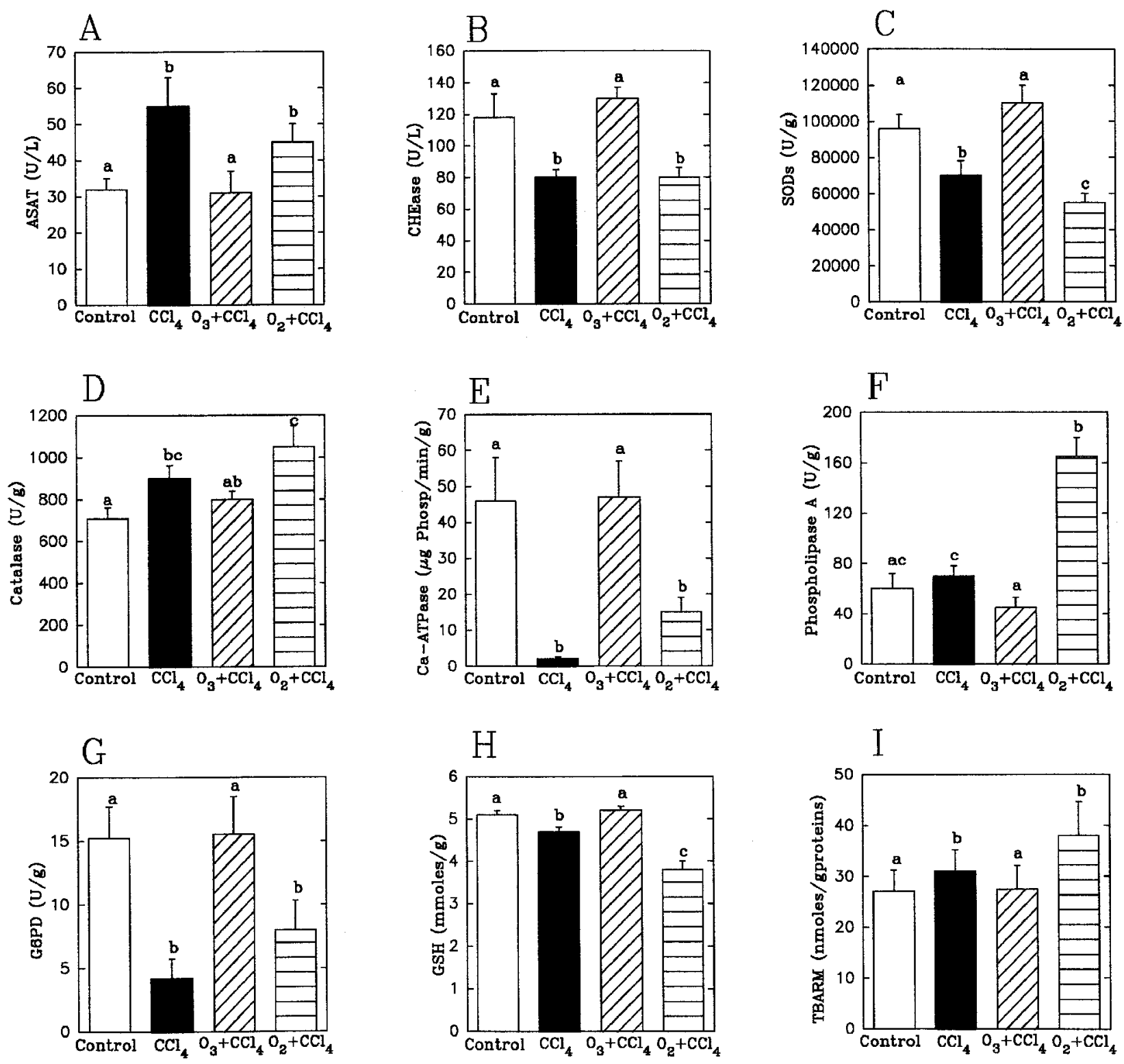

FIG. 1. The effect of ozone oxidative preconditioning in preventing $\mathrm{CCl}_{4}$ damage in rats. The white and black bars represent either the negative or the positive controls, respectively. The hatched bars represent the situation either after $\mathrm{O}_{3}$ exposure (diagonal lines) or after $\mathrm{O}_{2}$ exposure (horizontal lines), respectively, prior to $\mathrm{CCl}_{4}$. Values represent mean $\pm \mathrm{SEM}$.

respect to the control group. Ca-ATPase activity markedly decreased with $\mathrm{CCl}_{4}$ and the $\mathrm{O}_{2}+\mathrm{CCl}_{4}$ treatments in comparison with both the control and $\mathrm{O}_{3}+\mathrm{CCl}_{4}$ treatment groups. The phospholipase A concentration in the $\mathrm{O}_{3}+\mathrm{CCl}_{4}$ group did not differ from the control group and it was significantly lower in comparison with the $\mathrm{CCl}_{4}$ and the $\mathrm{O}_{2}+\mathrm{CCl}_{4}$ treatment groups. The latter group was markedly increased in comparison with the control group. G6PD was significantly reduced in both the $\mathrm{CCl}_{4}$ and $\mathrm{O}_{2}+\mathrm{CCl}_{4}$ groups, while $\mathrm{O}_{3}$ treatment prior to $\mathrm{CCl}_{4}$ maintained the enzyme at a control level. Interestingly, the $\mathrm{O}_{3}$ treatment was also able to preserve a normal GSH level while the $\mathrm{O}_{2}$ treatment $+\mathrm{CCl}_{4}$ markedly reduce it. In line with these results, the
TBARM, as an index of lipid peroxidation, was kept under control by the $\mathrm{O}_{3}$ treatment.

Data from group $5\left(\mathrm{O}_{3}\right)$ and group $6\left(\mathrm{O}_{2}\right)$, without the final challenge with $\mathrm{CCl}_{4}$ are not shown because they remained in the range of the control group, except phospholipase A levels were significantly $(P<$ $0.05)$ higher $(80.3 \pm 14.2)$ in the $\mathrm{O}_{2}$ group than control $(60.0 \pm 12.0)$.

Table 1 shows the qualitative results of the general hepatic damage (hepatocellular necrosis, ballonic degeneration, lipidosis and mesenchymal reaction) and the total amount of cells that have undergone ballonic degeneration (BD). In spite of a minimal degree of general hepatic damage and a marked reduction in the amount of cells with $\mathrm{BD}$, values from 
Table 1. Evaluation of the general hepatic damage in the three groups challenged with $\mathrm{CCl}_{4}$

\begin{tabular}{lcc}
\hline Groups & Degree & BD \\
\hline $\mathrm{CCl}_{4}$ & 1.4 & $51.0 \pm 22.2^{\mathrm{ab}}$ \\
$\mathrm{O}_{3}+\mathrm{CCl}_{4}$ & 0.2 & $6.2 \pm 6.2^{\mathrm{b}}$ \\
$\mathrm{O}_{2}+\mathrm{CCl}_{4}$ & 2 & $89.0 \pm 33.0^{\mathrm{a}}$ \\
\hline
\end{tabular}

Degree of hepatic damage: 1 , slight, 2, moderate, 3 , severe. Values are expressed by the mean \pm SEM.

rats treated with $\mathrm{O}_{3}+\mathrm{CCl}_{4}$ were not significantly different from those, highly variable, of the $\mathrm{CCl}_{4}$ treatment group. On the other hand, the morphometric evaluation of the hepatic damage by lipidosis (Table 2) demonstrated a significant reduction $(P<$ $0.05)$ of the damage area in the group treated with $\mathrm{O}_{3}$ in comparison with the $\mathrm{CCl}_{4}$ treatment group. No differences were observed between the $\mathrm{CCl}_{4}$ treatment group and the group treated with $\mathrm{O}_{2}+\mathrm{CCl}_{4}$.

\section{Discussion}

In order to test our hypothesis that prolonged administration of judicious doses of $\mathrm{O}_{3}$ may promote the phenomenon of oxidative preconditioning, we had to demonstrate that hepatocytes can become resistant to the damage induced by free radicals after $\mathrm{CCl}_{4}$ poisoning. The results obtained in the present work fully support this postulation. It is worth remembering that Murry et al. ${ }^{22}$ in 1986 proposed the concept of 'ischaemic preconditioning' obtained by several cycles of brief coronary occlusion eventually able to minimize myocardial damage after a severe heart ischaemia.

Our experimental results have show $n$ that repeated administration of a gas mixture composed of $\mathrm{O}_{2}-\mathrm{O}_{3}$ via the colorectal route can induce a sort of crosstolerance to free radicals released after one single dose of $\mathrm{CCl}_{4}$. On the contrary, experimental groups (2 and 4) treated with either $\mathrm{CCl}_{4}$ or $\mathrm{O}_{2}+\mathrm{CCl}_{4}$, respectively, displayed a significant cellular damage. These results were well correlated with the histopathological findings in regard to the degree of ballonic degeneration and lipidosis. It must be pointed out that administration of $\mathrm{O}_{3}$ in rats could be carried out

Table 2. Morphometric evaluation of the hepatic damage by lipidosis

\begin{tabular}{lc}
\hline Groups & Damage areas $\left(\mathrm{mm}^{2}\right)$ \\
\hline $\mathrm{CCl}_{4}$ & $0.0580 \pm 0.0248^{\mathrm{a}}$ \\
$\mathrm{O}_{3}+\mathrm{CCl}_{4}$ & $0.0287 \pm 0.0237^{\mathrm{b}}$ \\
$\mathrm{O}_{2}+\mathrm{CCl}_{4}$ & $0.0512 \pm 0.0240^{\mathrm{a}}$ \\
\hline
\end{tabular}

Values are expressed by the mean \pm SEM. neither by inhalation, due to its toxicity, ${ }^{23,24}$ nor by ozonated autohaemotherapy for technical reasons. Nonetheless the colorectal route, although somew hat empirical, is easy, practical, atoxic and has the rationale that ozonated products reach the liver via portal circulation. ${ }^{25}$ Taking into account an interspecies factor based on the murine metabolic rate, a correct dose of ozone is $1 \mathrm{mg} / \mathrm{kg}$ in the rat and $0.25 \mathrm{mg} / \mathrm{kg}$ in humans, respectively. SODs and catalase are recognized scavengers of reactive oxygen spe$\operatorname{cies}^{26}$ and they have been tested as therapeutic agents against cellular damage induced by ischaemia ${ }^{27,28}$ in spite of their low bioavailability and antibody formation. The significant stimulation of endogenous SODs in $\mathrm{O}_{3}+\mathrm{CCl}_{4}$ group in comparison w ith $\mathrm{CCl}_{4}$ and $\mathrm{O}_{2}+$ $\mathrm{CCl}_{4}$ groups, suggests cellular protection most likely through the reduction in the availability of superoxide anion $\left(\bullet \mathrm{O}_{2}^{-}\right)$. This result was somewhat expected on the basis of several findings ${ }^{29-31}$ reporting increased activities of SOD, catalase and peroxidases after chronic $\mathrm{O}_{3}$ exposure. It is notew orthy that plants can also express a protective response to $\mathrm{O}_{3}{ }^{32-34}$ suggesting that living organisms chronically exposed to $\mathrm{O}_{3}$ have the option of either programming their death or to react and survive by upregulating the antioxidant defence system capable to readjust the redox balance. Moreover in patients, we and others have found $d^{7,25,35}$ that calculated, transient oxidative stresses such as those obtained during a cycle of ozonated autohaemotherapy can also induce a state of tolerance characterized by a simultaneous overexpression of SOD, G6PD and possibly a reduction of TBARM levels in plasma. The rectal insufflation of $\mathrm{O}_{3}$ (group 3) is apparently able to enhance the antioxidant system in a coordinate fashion because the increased activity of catalase on its own (groups 2 and 4) is unable to quench $\mathrm{CCl}_{4}$ toxicity.

It is know $n$ that an increase of intracellular $\mathrm{Ca}^{2+}$ concentration plays an important role in the damage and cellular death, representing a critical and early event in the development of toxicity of hepatocytes submitted to oxidative stress. ${ }^{36}$ The suggestion that free radicals may affect the activity of the Ca-ATPase, thus contributing to the hepatocellular injury, ${ }^{37}$ is well supported by our data because the Ca-ATPase activity was severely inhibited in groups 2 and 4 while the $\mathrm{O}_{3}$ treated group equalized the control. Indeed it has been previously shown that $\mathrm{Ca}^{2+}$-ATPase enzymes have critical thiol groups rapidly inactivated by ROS. ${ }^{38,39}$ Calcium-dependent phospholipase A activity was decreased in the $\mathrm{O}_{3}+\mathrm{CCl}_{4}$ treatment group indicating that ozone exerted indirectly a protection against the cellular disruption, mediated by the activation of an enzyme which generates lysophospholipids and other me tabolites responsible for cellular lys is. The increased phospholipase A activity in the fourth $\left(\mathrm{O}_{2}+\mathrm{CCl}_{4}\right)$ group suggests the participation of this enzyme in the hepatocellular damage noted in the histopathologic 
studies. $\mathrm{CCl}_{4}$ poisoning on its ow n caused only a modest increase of phospholipase A activity with respect to the control, probably due to the moderate character of the oxidative challenge after one single dose of $\mathrm{CCl}_{4}$. The greater cellular damage observed after oxygen administration plus the hepatotoxic treatment indicates the deleterious effect of hyperoxygenation. ${ }^{10,11}$ Sustained levels of GSH and G6PD can be taken as reliable markers of antioxidant defenses in the face of an oxidative challenge. Finally the decrease in hepatic lipid peroxidation obtained in the $\mathrm{O}_{3}+\mathrm{CCl}_{4}$ group was in good agreement with the reduction of the lipidosis observed in the histopathologic studies, while under $\mathrm{CCl}_{4}$ and $\mathrm{O}_{2}+\mathrm{CCl}_{4}$ treatments lipid peroxidation levels were raised significantly. Why the $\mathrm{O}_{3}$ treatment, without the final challenge with $\mathrm{CCl}_{4}$ (Group 5), did not show a significant increase of antioxidant enzymes may be explained by either the fairly short treatment or, more likely, by the fact that $\mathrm{O}_{3}$ acts best when there is an ongoing oxidative insult.

In conclusion, the present study contributes to clarify an important pharmacodynamic effect after prolonged ozonetherapy in rats. The phenomenon can be described as an induction of tolerance to $\mathrm{O}_{3}$ and ROS generated by toxic agents and has been denominated as either 'oxidative preconditioning', or 'oxidative stress adaptation'. ${ }^{25}$ Ozonetherapy has been able to preserve liver integrity by inducing either enzymes or activating metabolic pathways that maintain an equilibrated redox balance. High SODs and GSH levels, low peroxidation and a normal $\mathrm{Ca}^{2+}$ homeostasis are clear examples of the efficacy of ozonetherapy. We believe that the possibility shown by appropriate ozonetherapy to upregulate the antioxidant system represents a fundamental property of this complementary medical approach and that $\mathrm{O}_{3}$ comes to typify a unique drug. In fact exogenous administration of antioxidant substances such as ascorbic acid, GSH, $n$-acetyl cysteine, SOD and the like are useful but hardly able to dramatically reverse a chronic oxidative stress. In this sense the improvement of the antioxidant defence is bound to be crucial in cancer, ${ }^{40}$ chronic viral infections ${ }^{41}$ and neurodegenerative diseases, ${ }^{42}$ where the control of endogenous oxidation has gone awry with progressive cell damage. Therefore we should most actively pursue this lead for improving the therapy of these diseases.

\section{References}

1. Devesa E, Menéndez S, Rodrốguez MM, Gómez M, Garcôn J. Ozone therapy in ischemic cerebro-vascular disease. In: Proceedings 11th Ozone World Congress (USA) Ozone in Medicine 1993; M-4-10-M$4-18$

2. Werkmeister H. Dekubitalgeschwüre und die Behandlung mit der OzonUnterdruckbegasung. In: Beck, Viebahn-Hänsler, eds. Ozon-Handbuck. Grundlagen. Prävention. Therapie. Landsberg/Lech: Ecomed, 1995; $\mathrm{V}-7.11-\mathrm{V}-7.12$
3. Romero A, Menéndez S, Gómez M, Ley J. Ozone therapy in the advanced stages of arteriosclerosis obliterans. An gio logóa 1993; 45: 146-148.

4. Menéndez S, Peláez O, Gómez M, Copello M. Application of ozone therapy in Retinitis Pigmentosa. Revista CNIC Ciencias Biológicas 1989 20: $84-90$.

5. Menéndez S, Iglesias O, Bidot C, Puga R, Carballo A. Application of ozone therapy in children with humoral immunity deficiency. In: International Ozone Association, ed. Proceedings 12th Ozone World Congress, Ozone in Medicine. Lille 1995; 271-274.

6. Wong R, Rivero R, Menéndez S, Gómez M. Ozone therapy in liver steatosis. Revista CNIC Ciencias Biológicas 1989; 20: 157-159.

7. Hernández F, Menéndez S, Wong R. Decrease of blood cholesterol and stimulation of antioxidative response in cardiopathy patients treated with endovenous ozone therapy. Free Rad Biol Med 1995; 19: 115-119.

8. Editorial. Ozone: too much in the wrong place. Lancet 1991; 338 221-222.

9. Pryor WA. How far does ozone penetrate into the pulmonary air/tissue boundary before it reacts? Free Rad Biol Med 1992; 12: 83-88.

10. Pryor WA, Church DF. Aldehydes, hydrogen peroxide and organic radicals as mediators of ozone toxicity. Free Rad Biol Med 1991; 11: 41-46.

11. Groot H, Noll T. Studies on the ox ygen dependence of lipid peroxidation. In: Nigam et al., eds. Eicosanoids, Lipid Peroxidation and Cancer. Berlin Heidelberg: Springer-Verlag, 1988; 215-220.

12. Boehringer Mannheim. Biochemica Information. A revised biochem ical reference source. Enzymes for routine (1st edition), Germany: Boehringer Mannheim, 1987; 80-81.

13. Boehringer Mannheim. Biochemica Information. A revised biochem ical reference source. Enzymes for routine (1st edition), Germany: Boehringer Mannheim, 1987; 15-16.

14. Hotter G, León OS, Catafau-Roselló J, et al. Tissular prostanoid release phospholipase A2 activity and lipid peroxidation in pancreas transplantation. Transplantation 1991; 51: 987-990.

15. Makris PE, Tsairis DA. The ratio MDA/MDA2 as a new index of platelet hyperactivity. Haemostasis $1975 ; 15: 331-336$.

16. Harvald B, Hanel KH, Squires R. Adenosine-triphosphatase. Deficiency in patients with non-spherocytic haemolytic anaemia. Lancet 1964: II(7349) : $18-19$.

17. Ames NB. Assay of inorganic phosphate, total phosphate and phosphatases. In: Colow ick SP, Kaplan eds. Methods in Enzymology (VIII). New York: Acade mic Press, 1972; 115-118.

18. Grassi M, Walter HE. In: Bergmeyer HU, ed. Methods of Enzymatic Analysis (3rd ed., Vol. 2). Weinheim, W. Germany-Deerfield Beach, FL VCH, 1983; 202-203

19. Ecobichon DJ. Glutathione depletion are resynthesis in laboratory animals. Drug Chem Toxicol 1984; 7: 345-355.

20. Spector T. Refinement of the coomassie blue method of protein quantification. Anal Biochem 1978; 86: 142-146.

21. Rodrốguez R, Fernández-Brito JE, Wong R, Campos R, Falcón L. MADIP, analytic morphometric and digitalization in pathology: software for diagnostic and investigation. Rev Cub Invest Biomed 1992; 11: $126-128$

22. Murry CE, Jennings RB, Reimer KA. Preconditioning with ischemia: a delay of lethal cell injury in ischemic myocardium. Circulation 1986; 74 $1124-1136$

23. Cross CE, Eiserich JP, Halliwell B. General biological consequences of inhaled environmental toxicants. In: Crystal RG, West JB, eds. The Lung: Scientific Foundations. Philadelphia: Lippincott-Raven Publishers, 1997; 2421-2437.

24. van Hoof HJM, Zijlstra FJ, Voss H-P, et al. The effect of ozone exposure on the release of eicosanoids in guinea-pig BAL fluid in relation to cellular damage and inflammation. Mediators Inflamm 1997; 6: 355-361.

25. Bocci V. Ozone as a bioregulator. Pharmacology and toxicology of ozonetherapy today. J Biol Regulat Homeost Agent 1996; 10: 31-53.

26. Brent JA, Rumack BH. Role of free radicals in toxic hepatic injury. Clin Toxicol 1993; 31: 139-171.

27. Castillo M, Toledo-Pereyra IH, Shapisco E, Guerra E, Prough D, Frantzis P. Protective effect of allopurinol, catalase and superoxide dismutase in ischemic rat liver. Transplant Proc 1990; 22: 490-491.

28. Oyanagui Y, Sato S. Superoxide dismutases and antioxidants protected mice from no-reflow and necrotic damage induced by ischemia. Free Rad Res Comm 1993; 18: 147-157.

29. Chow CK, Tappel AL. Activities of pentose shunt and glycolytic enzymes in lungs of ozone-exposed rats. Arch Environ Health 1973; 26 205-208

30. Rahman I, Clerch LB, Massaro D. Rat lung antioxidant enzyme induction by ozone. Am J Physiol 1991; 260: L412-L418.

31. Weller BL, Crapo JD, Slot J, Posthuma G, Plopper CG, Pinkerton KE. Siteand cell-specific alteration of lung copper/zinc and manganese superoxide dismutases by chronic ozone exposure. Am J Respir Cell Molec Biol 1997; 17: 552-560.

32. Kangasjärvi J, Talvinen J, Utriainen M, Karjalainen R. Plant defence systems induced by ozone. Plant Cell Environ 1994; 17: 783-794.

33. Ranieri A, D'Urso G, Nali C, Lorenzini G, Soldatini GF. Ozone stimulates apoplastic antioxidant systems in pumpkin leaves. Physiol Plant 1996; 97: $381-387$. 
34. Sharma YK, Davis KR. The effects of ozone on antioxidant responses in plants. Free Rad Biol Med 1997; 23: 480-488.

35. Bocci V. Does ozone the rapy normalize the cellular redox balance? Med Hypotheses 1996; 46: 150-154.

36. Nakano $H$, Monden $M$, Umeshita $K$, et al. Protective effects of prostaglandin 12 analogues on superoxide induced hepatocyte injury. Annals New York Academy of Sciences 1993; 723: 447-450.

37. Watanabe $\mathrm{H}$, Onda M, Genga A, Asano G. The role of $\mathrm{Ca}(2+)$-ATPase and oxygen radical in reperfusion injury of rat liver. Nippon-Geka-GakkaiZasshi 1993; 94: 1269-1276.

38. Ariki M, Shamoo AE. Oxidation of reactive sulfhydryl groups of sarcoplasmic reticulum ATPase. Biochem Biophys Acta 1983; 734: $83-90$.

39. Scherer NM, Deamer DW. Oxidative stress impairs the function of sarcoplasmic reticulum by oxidation of sulfhydryl groups in the $\mathrm{Ca}^{2+}$ ATPase. Arch Biochem Biophys 1986; 246: 589-601.
40. Toyokuni S, Okamoto K, Yodoi J, Hiai H. Persistent oxidative stress in cancer. FEBS Lett 1995; 358: 1-3.

41. Schwarz KB. Oxidative stress during viral infection: a review. Free Rad Biol Med 1996; 21: 641-649.

42. Simonian NA, Coyle JT. Oxidative stress in neurodegenerative diseases. Annu Rev Pharmacol Toxicol 1996; 36: 83-106.

ACKNOWLEDGEMENTS. V.B. is particularly grateful to Mrs Helen Carter and Patrizia Marrocchesi for carefully editing the manuscript. A partial support by Murst national (40\%) and local (60\%) funds to V.B. is acknowledged.

\section{Received 7 April 1998;}

accepted in revised form 28 May 1998 


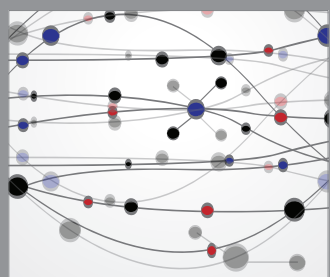

The Scientific World Journal
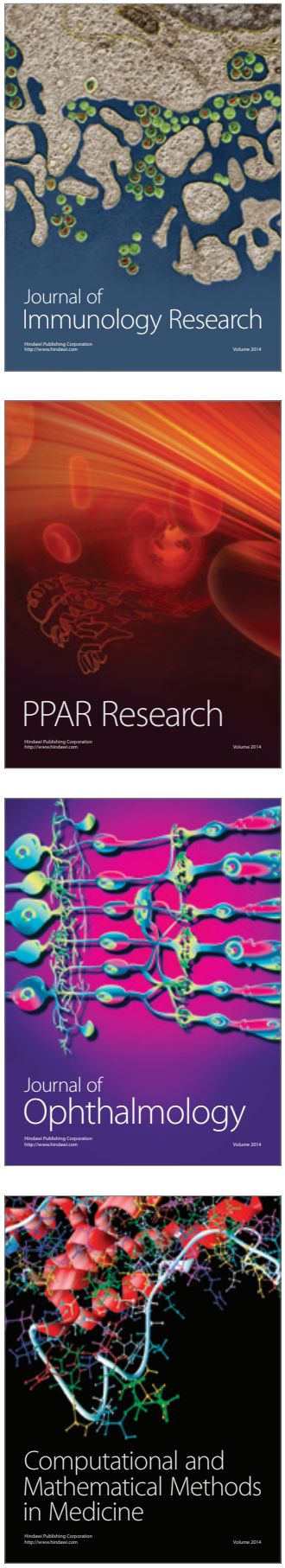

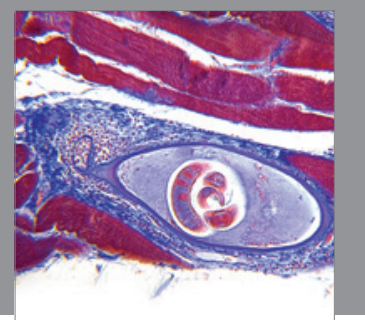

Gastroenterology

Research and Practice
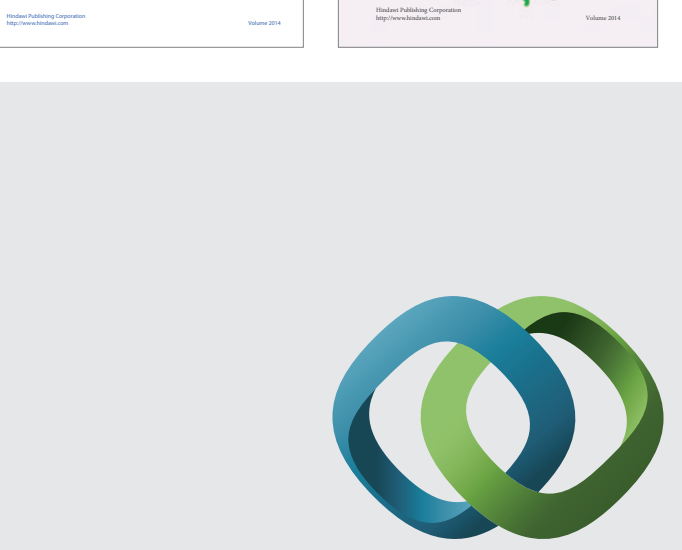

\section{Hindawi}

Submit your manuscripts at

http://www.hindawi.com
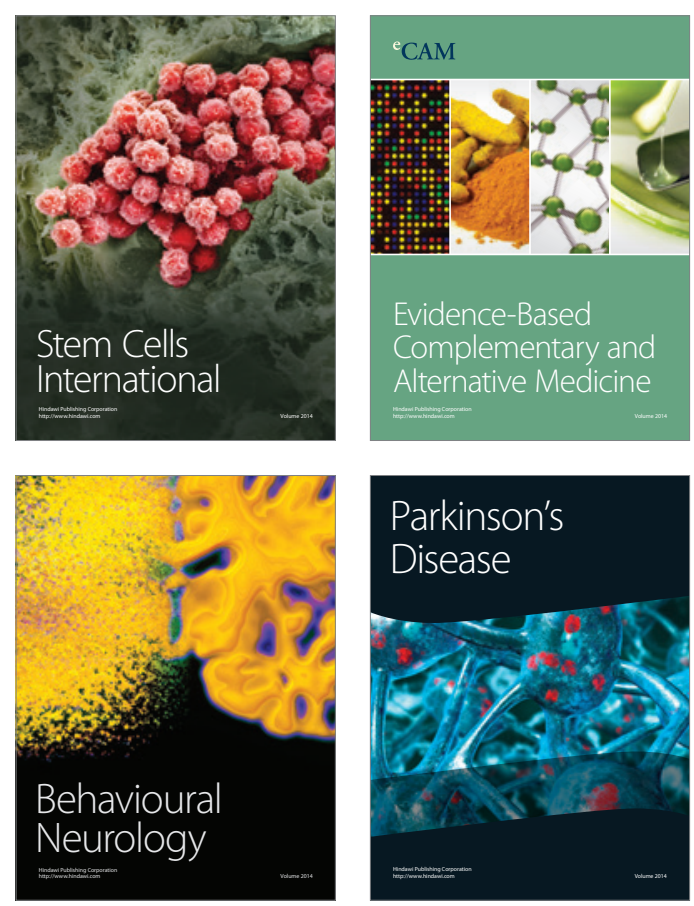

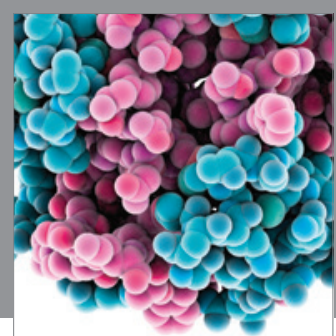

Journal of
Diabetes Research

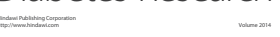

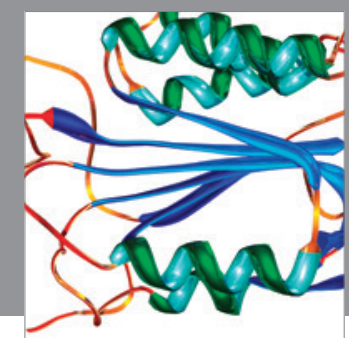

Disease Markers
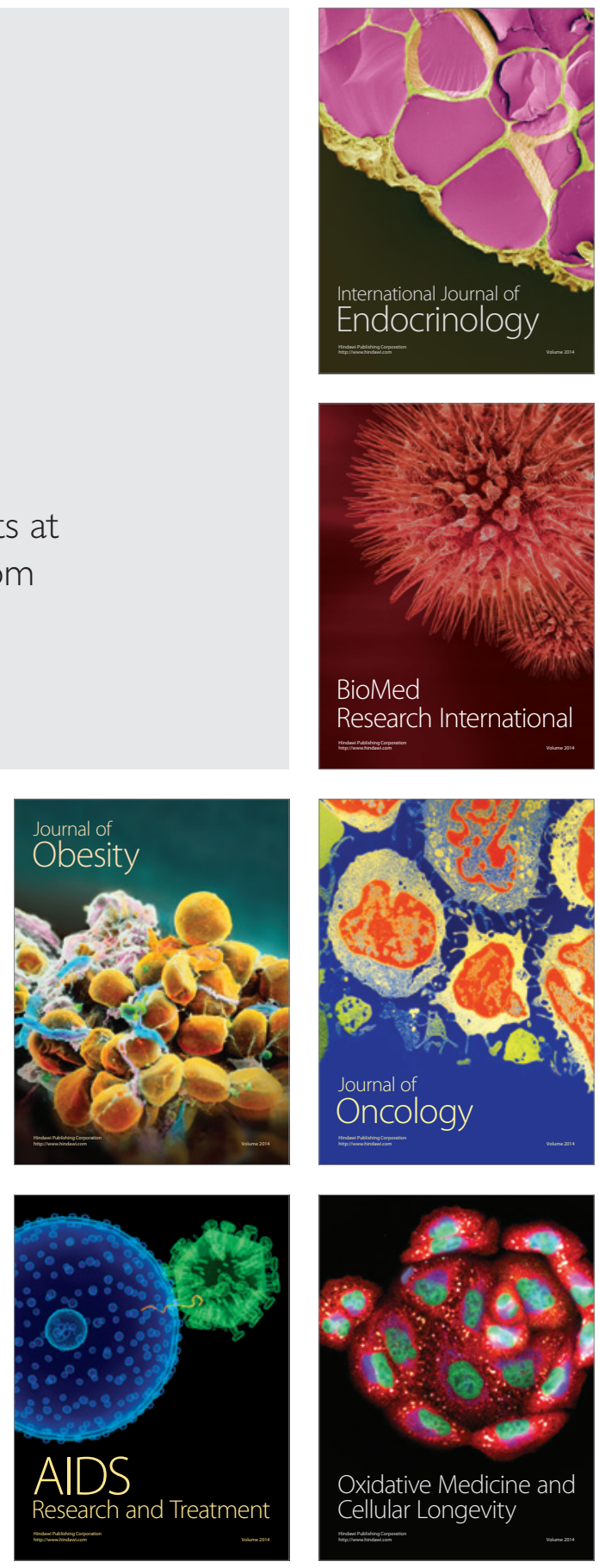